FACTA UNIVERSITATIS

Series: Physical Education and Sport, Vol. 16, No 3, 2018, pp. 569 - 576

https://doi.org/10.22190/FUPES180225051M

Research article

\title{
EFFECTS OF AN EXPERIMENTAL MODEL OF EXPLOSIVE STRENGTH IN REGULAR PHYSICAL EDUCATION CLASSES
}

\author{
UDC 796.012.52 \\ 796. -053.5
}

\author{
Vladimir Momčilović, Zoran Momčilović, Stojan Cenić \\ Pedagogical Faculty in Vranje, University of Niš, Vranje, Serbia
}

\begin{abstract}
The study was conducted with the goal to determine the effects of explosive strength training on the transformation of motor skills and functional abilities during regular physical education (PE) classes, among primary school students. The sample of participants consisted of 64 pupils from Niš, 14 years old. The experimental group comprised 32 participants, selected for training of the experimental model of explosive strength in the main part of regular PE classes, three times per week, for a duration of 45 minutes, for a period of eight weeks. One half of these classes was dedicated to a regular $P E$ curriculum, while the other half to an experimental program of explosive strength, for a duration of eight weeks. The control group also comprised 32 participants, who attended regular PE classes, three times a week for a duration of 45 minutes, for a period of eight weeks. The following motor skills were assessed: coordination (two tests), sprint speed (two tests), repetitive strength (two tests), and explosive strength (two tests). The following functional abilities were assessed: pulse frequency after physical activity, Margaria test, and vital lung capacity. For processing data, a variance and covariance analysis were applied. The study results showed that the experimental group of participants achieved better results in motor skills and functional abilities, as well as that there were statistically significant effects at the final testing.
\end{abstract}

Key words: explosive strength training, motor skills, functional abilities, primary school students, effects

Received February 25, 2018 / Accepted December 21, 2018

Corresponding author: Vladimir Momčilović

University of Niš, Pedagogical Faculty in Vranje, Partizanska 14, 17500 Vranje, Serbia

Phone: +381 17422962 •E-mail: vladmomcilovic@gmail.com 


\section{INTRODUCTION}

Physical education (PE) classes essentially present an adaptive process by which students, as one system, have a transition from one into a different condition, in accordance with the established course of the curriculum.

In the field of anthropological features of students, besides the investigation of the structure of certain fields and their segments, in recent years the problems in the area of testing the transformation process of certain programs of motor skills exercises into the development of anthropological features have been a prominent issue, bearing in mind that there are large differences in sensitive phases among genders and age groups (Višnjić, 2006).

Studies conducted on different samples of participants, athletes and non-athletes, defined positive adaptation changes in abilities and traits, as well as motor skills under the influence of various teaching models during regular PE classes (Milošević, 1997, in Momčilović \& Momčilović, 2016).

In order to achieve efficient management of the teaching process, the PE curriculum needs to use transformation processes. It is also necessary to be familiar with the structure of the dimension of anthropological characteristics and their influence on the efficiency of performing certain motor skills.

Recent studies of Zatsiorsky \& Kraemer (2006); Ljuština \& Pribić (2007); Ćavar, Glibić, \& Markota (2009); Memagić, Balić, Novaković, Bilić, \& Redžić (2011) indicate that applying explosive strength exercises during PE classes contributes to the development of morphological dimensions, motor skills and functional abilities relevant for achieving quality performance in sport, perfecting of new and versatile motor structures (skills, technique and tactics), determining, monitoring and improving health status, as well as all other segments (psychological, sociological) relevant to primary school students.

The resulting change in traits, abilities and motor skills is also affected by the total duration of the exercise process. It can be assumed that among primary school students, explosive strength programs influence better-quality adaptation processes of the body, by increasing motor skills and functional abilities. So far, there have not been much studies performed upon this topic and this sample of participants.

The aim of this longitudinal research were to determine the effects of an explosive strength program on motor skills and functional abilities in primary school students, within regular PE curricula, in order to provide reliable data that would serve as a basis for undertaking eventual corrective measures and improvement of efficiency of regular PE classes in primary schools in Serbia.

\section{METHODS}

The sample consisted of 64 healthy, male elementary school students from Niš, 14 years old ( \pm 6 months), who have regularly been attending PE classes.

Both the experimental and control group consisted of 32 participants each. The experimental group followed a specially designed explosive strength training program during the first half of the classes, while the other half was dedicated to the regular PE curriculum (totally 45 minutes long), three times per week, for a period of eight weeks. 
Standard motor tests were used in the assessment of motor skills of both groups of participants, according to Šoše and Rađo (1998): acrobatic agility in the air - MOKV MAA, and coordination with a baton - MCS (coordination expressed in s); $20 \mathrm{~m}$ running from a flying start - M20FS, and 50m running from a standing start - M50SS (sprint speed expressed in s); squats $M S Q U A$, and push-ups - MPUPS (repetitive strength expressed in frequency); the standing long jump - MSLJ, and standing triple jump - MSTJ (explosive strength expressed in $\mathrm{cm}$ ).

For assessment of the functional abilities, the following tests were applied: pulse frequency after the load - FPFL (expressed in bpm), the Margaria test - FMAR (expressed in s), and vital lung capacity - FVC (expressed in $\mathrm{cm}^{3}$ ). Measurement was conducted by the procedures proposed in the study of Heimer \& Medved (1997).

Data were obtained at the beginning and the end of a 8-week program of explosive strength that consisted of the following explosive strength exercises: knee tuck jumps; vertical one-leg jumps over a hurdle (height 20-30 cm); side jumps over a hurdle (height $40-50 \mathrm{~cm}$ ); one-leg vertical jumps (left and right leg); low and high knee skips; squat jumps; height-variation bench jumps; jumps over lower obstacles (with both leg and with one leg); various methods of jump rope; rhythmic jumps with trail leg lifting at different amplitudes; vertical jumps with knee to chest leg raising; and similar exercises. For developing anaerobic capacity sprints were predominantly used with maximum speed and an intensity of $60-80 \%$, with a heartbeat frequency of $150-170$ beats per minute, and with a full recovery period between repetition sets. Functional ability exercises were aimed at perfecting abilities of rapid muscle engagement, i.e., speed-strength, while for the development of stamina, focus was on improving speed-strength stamina, also.

The impact of regular PE classes on the control group was oriented towards the development of anthropologic features and increasing the level of technical-tactical skills.

\section{RESULTS}

Table 1 Multivariate analysis of covariance between the experimental and control group in the field of motor skills at the initial testing

\begin{tabular}{ccccc}
\hline Wilks' Lambda & F-ratio & df 1 & df 2 & P-level \\
\hline .784 & 4.86 & 8 & 64 & .002 \\
\hline
\end{tabular}

Legend: value of Wilks' Lambda test, value of F-test (F-ratio), total number of tests (df 1), total number of examinees ( $\mathrm{df} 2$ ) and level of significance (P-Level)

The multivariate analysis of covariance in the field of motor skills (Table 1) indicates that there is statistically significant difference at the multivariate level between participants of experimental and control group, on a significance level higher than .01 (Plevel $=.002)$, which was also confirmed by the value of Wilks' Lambda test $(.784)$ and Ftest (4.86). Existing difference occurs under the impact of experimental treatment which had an effect on the development of the motor skills of the experimental group. 
Table 2 Univariate analysis of covariance between the experimental and control group regarding motor skills at the final testing with neutralization of differences at the initial testing

\begin{tabular}{|c|c|c|c|c|c|}
\hline Motor skills tests & $\mathrm{N}$ & Groups & Mean & F-ratio & P-Level \\
\hline MAA (in s) & 32 & Experimental & 15.20 & 5.64 & .000 \\
\hline MCS (in s) & $\begin{array}{l}32 \\
32\end{array}$ & $\begin{array}{l}\text { Experimental } \\
\text { Control }\end{array}$ & $\begin{array}{l}12.60 \\
14.53\end{array}$ & 3.87 & .031 \\
\hline M20FS (in s) & $\begin{array}{l}32 \\
32\end{array}$ & $\begin{array}{l}\text { Experimental } \\
\text { Control }\end{array}$ & $\begin{array}{l}3.15 \\
4.10\end{array}$ & 7.26 & .000 \\
\hline M50SS (in s) & $\begin{array}{l}32 \\
32\end{array}$ & $\begin{array}{c}\text { Experimental } \\
\text { Control }\end{array}$ & $\begin{array}{l}7.42 \\
8.85\end{array}$ & 5.43 & .000 \\
\hline MSQUA (in freq.) & $\begin{array}{l}32 \\
32\end{array}$ & $\begin{array}{c}\text { Experimental } \\
\text { Control }\end{array}$ & $\begin{array}{l}16.00 \\
14.00\end{array}$ & 2.85 & .071 \\
\hline MPUPS (in freq.) & $\begin{array}{l}32 \\
32 \\
\end{array}$ & $\begin{array}{c}\text { Experimental } \\
\text { Control }\end{array}$ & $\begin{array}{r}12.00 \\
9.00 \\
\end{array}$ & 5.76 & .000 \\
\hline MSLJ (in cm) & $\begin{array}{l}32 \\
32 \\
\end{array}$ & $\begin{array}{c}\text { Experimental } \\
\text { Control } \\
\end{array}$ & $\begin{array}{l}163.00 \\
138.00 \\
\end{array}$ & 6.73 & .000 \\
\hline MSTJ (in cm) & $\begin{array}{l}32 \\
32\end{array}$ & $\begin{array}{c}\text { Experimental } \\
\text { Control }\end{array}$ & $\begin{array}{c}530.00 \\
460.00\end{array}$ & 6.82 & .000 \\
\hline
\end{tabular}

Legend: number of participants (N), Mean (average value), value of F-test (F-ratio) and level of significance (P-Level)

The univariate level of analysis of covariance between the experimental and control group in the tests for the assessment of motor skills at the final testing with a neutralization and partialization of the results on the initial testing is shown in Table 2. A statistically significant effect on six of the tests was determined, at the reliability level of $99 \%$, for acrobatic agility (MAA .000), 20m running with flying start (M2OFS .000), 50m running with standing start (M50SS .000), pushups (MPUPS .000), standing long jump (MSLJ .000) and standing triple jump (MSTJ .000). For one of the tests $(M C S)$ the difference is statistically significant at the level of .05 . Only for one of the tests, i.e., squats, was the difference not statistically significant (MSQUA .071).

Table 3 Multivariate analysis of covariance between the experimental and control group in the field of functional abilities at the initial testing

\begin{tabular}{ccccc}
\hline Wilks' Lambda & F-ratio & df 1 & df 2 & P-level \\
\hline .754 & 4.38 & 3 & 64 & $\mathbf{. 0 0 4}$ \\
\hline
\end{tabular}

Legend: value of Wilks' Lambda test, value of F-test (F-ratio), total number of tests (df 1), total number of participants (df 2) and level of significance (P-Level)

The multivariate analysis of covariance in the field of functional abilities (Table 3), indicates that there is a statistically significant difference at the multivariate level between the participants of the experimental and control group, on the significance level higher than $.01($ P-level $=.004)$, which is also confirmed by the value of Wilks' Lambda test (.754) and F- test (4.38). The existing difference occurs under the impact of experimental treatment which had an effect on the development of the functional abilities of the experimental group. 
Table 4 Univariate analysis of covariance between the experimental and control group regarding functional abilities at the final testing with a neutralization of differences at the initial testing

\begin{tabular}{|c|c|c|c|c|c|}
\hline Functional abilities tests & $\mathrm{N}$ & Groups & Mean & $\mathrm{F}$ & P-Level \\
\hline FPFL (in bpm) & $\begin{array}{l}32 \\
32\end{array}$ & $\begin{array}{c}\text { Experimental } \\
\text { Control }\end{array}$ & $\begin{array}{l}156.68 \\
164.36\end{array}$ & 5.76 & .000 \\
\hline FMAR (in s) & $\begin{array}{l}32 \\
32\end{array}$ & $\begin{array}{c}\text { Experimental } \\
\text { Control }\end{array}$ & $\begin{array}{l}3.42 \\
3.95\end{array}$ & 4.95 & .021 \\
\hline $\mathrm{FVC}\left(\right.$ in $\left.\mathrm{cm}^{3}\right)$ & $\begin{array}{l}32 \\
32\end{array}$ & $\begin{array}{c}\text { Experimental } \\
\text { Control }\end{array}$ & $\begin{array}{l}3854.00 \\
3620.60\end{array}$ & 2.96 & .613 \\
\hline
\end{tabular}

Legend: number of participants ( $\mathrm{N})$, Mean (average value), value of F-test (F-ratio), and level of significance (P-Level)

The univariate level of analysis of covariance between the experimental and control group in the tests for assessment of functional abilities on the final testing with a neutralization and partialization of the results at the initial testing (Table 4) indicates that there is statistically significant effect on pulse frequency after load (FPFL .000) at a level of reliability of $99 \%$. For the Margaria test (FMAR .021) the difference is statistically significant at the level of .05. Only for the vital lung capacity test was difference not statistically significant $(F V C .613)$.

\section{DISCUSSION}

The conducted study confirmed that there are effects of the explosive strength model of training on the motor and functional abilities among primary school students. It has been proved that with appropriate organisational and methodical aspects of work during PE classes, continuous improvement of pupils' motor and functional abilities can be more efficiently achieved.

The multivariate analysis of covariance between the experimental and control group in terms of motor skills on the final testing with the neutralization of differences at the initial testing (Table no. 1) showed that, under the influence of the experimental model of explosive strength, there were statistically significant changes at the level of motor skills (PLevel $=.002)$. At the initial testing, there were no statistically significant differences between the tested motor skills of the experimental and control group, since the participants had approximately the same level of these skills.

The method of maximum speed performance of parts of the elements or the entire technique was used to increase the level of explosive strength (in facilitated or difficult conditions). Intensities were between $5 \%$ to $10 \%$ of maximum intensity, characteristic for performing the complete technique in certain situational-motor exercises in collective sport games.

The sensitive period for development of explosive strength among boys are ages 14 to 15 , and among girls ages 9 to 12 . The level of innateness is above $80 \%$. The most important factors that influences explosive strength are the nervous and muscular system and their mutual compliance. In the muscular system the relation between red (slow twitch) and white (fast twitch) muscle fibers is of the significance. The magnitude of explosive strength is determined by the ability to strain mutually a large number of muscle groups that are 
engaged in movement, in conditions of full inter-muscular coordination, as well as by the most optimal relation of speed and strength components.

According to Čoh (2004) and Duraković (2007) this can also be explained with appropriate organization of the curriculum, especially in the process of course planning, frequency, distribution and control of applied intensities of the exercises, as well as intensification of work in accordance with authentic requirements of the participants.

In the process of realization of a more complex structure of motor skill exercises of the experimental i.e., explosive strength program, emphasis was put on proper posture, hand movement, hips, knees and feet position, as well as on the development of proprioceptive feelings and awareness of the body axis position, so that all the mentioned parameters could later be implemented into development of basic movements, either anteroposterior, transversal or vertical, and to ultimately achieve a connection between these movements and the total motor structure of movement.

The results of the multivariate analysis of covariance between the experimental and control group in terms of functional abilities at the final testing with a neutralization of differences at the initial testing (Table 3) also show that, under the influence of an experimental i.e., explosive strength program, there were statistically significant changes in functional abilities (P-Level $=.004)$

Adaptive changes in functional abilities at the end of the research in the experimental group are probably a consequence of the improved phosphocreatine and glycolytic energy mechanisms, and increased efficiency of the nerve structures in specific conditions of oxygen debt (Heimar \& Medved, 1997), due to maximum speed sprints, with full recovery between repetitions.

Optimal change in exercise and rest intervals during the training process for the development of functional abilities, according to Jukić (1998); Matković (1998); Bosquet, Leger, \& Legros (2002); Godina, Khomyakova, Purundzhan, Tretyak, \& Zadorozhnaya (2007), contributes to the increase of performance abilities in comparison with the initial level. The increase in the performance abilities is in that case based upon a positive functional reaction of the body, which enables a further increase and development of the fitness level.

Researchers whose scope of interest was development of functional abilities in athletes (Rakovac \& Heimar, 2003; Beets \& Pitetti, 2005; Hawkins, Raven, Snell, Stray-Gundersen, \& Levine, 2007; Malacko \& Doder, 2008) supported such a concept of functional preparation of students by means of an explosive strength program during PE classes.

\section{CONCLUSION}

The PE curriculum (methods, instruments, scope and intensity of physical activity, individualisation), which is significant for the effective development of motor skills and functional abilities, and which can contribute to rationalisation and optimalisation of PE classes, is of a complex structure.

Data obtained in the current research can be used as a baseline for PE teachers, and a more adequate approach to planning, programming, conducting and controlling of the teaching process, and for efficient guidance and selection of prospective athletes and further development of skills and traits among children of this age. 
The research results, as well as the complete content and concept of the explosive strength program, could serve as a baseline in reviewing, changing or innovating existing PE curricula in primary schools in Serbia.

\section{REFERENCES}

Beets, W.M., \& Pitetti, H.K. (2005). Contribution of physical education and sport to health related fitness in high school students. Journal of School Health, 75 (1), 25-30.

Bosquet, L., Leger, L., \& Legros, P. (2002). Methods to determine aerobic endurance. Sports Medicine, 32(11), 675-700.

Duraković, M (2007). Kinantropologija-Biološki aspekti telesnog vežbanja (Kinantropology-Biological aspects of physical exercise). Zagreb: Faculty of Kinesiology. In Croatian

Čoh, M. (2004). Metodika i dijagnostika razvoja skočnosti u kondicijskoj pripremi sportaša. Kondiciona priprema sportista (Methodics and diagnostics of vertical jump development in physical conditioning of athletes. Conditioning preparation of athletes), Book of Proceedings (pp. 104-118). Zagreb: Faculty of Kinesiology. In Croatian

Ćavar, M., Glibić, M., \& Markota, M. (2009). Opravdanost dijagnostike funkcionalnih sposobnosti dece testovima isključivo aerobnoga karaktera (Justification for diagnosis of children's functional abilities only by aerobic tests). In I. Jukić, D Milanović, C. Gregov, \& S. Šalaj (Eds.), 7th Annual International Conference "Fitness Preparation for Athletes 2009". Book of Proceedings (pp.362-365). Zagreb: Faculty of Kinesiology. In Croatian

Godina, E., Khomyakova, I., Purundzhan, A., Tretyak, A., \& Zadorozhnaya, L. (2007). Effect of physical training on body composition in Moscow Adolescents. Journal of Physiological Anthropology, 26 (2), $229-234$.

Hawkins, M.N., Raven, P.B., Snell, P.G., Stray-Gundersen, J., \& Levine, B.D. (2007). Maximal oxygen uptake as a parametric measure of cardiorespiratory capacity. Medicine and Science in Sports and Exercise, 39, 103-107.

Heimar, S., \& Medved, R. (1997). Funkcionalna dijagnostika treniranosti sportaša (Functional diagnostics of fitness in athletes). International Counseling, Book of Proceedings (pp. 23-44). Zagreb: Faculty for Physical Culture. In Croatian

Jukić, I. (1998). The influence of programmed training on the functional abilities in young athletes. Kineziologija, 30 (1).

Ljuština, R., \& Pribić, T. (2007). Odnos testova plućne ventilacije prema uzrastu i visini mladića od 15 do 19 godina (Relation of tests of lung ventilation by stature and height of young boys aged 15 to 19). 46 Congress of Anthropological Society of Yugoslavia with International Participation, Banja JunakovićApatin, 29 May-2 June 2007.

Malacko, J, \& Doder, D. (2008). Tehnologija sportskog treninga i oporavka (The technology of sports training and recovery). Novi Sad: The Provincial Sports Institute. In Serbian

Matković, B. (1998). Longitudinalne promene aerobnog kapaciteta kod dječaka. Kineziologija 20(2), 81-88.

Memagić, A., Balić, A., Novaković, R., Bilić, M., \& Redžić, H. (2011). Parcijalne kvantitativne promene eksplozivne snage i agilnosti pod utjecajem posebnog programa (Partial quantitative changes of explosive strength and agility under the influence of special programs). Sportski logos, 9 (16-17), 21-25.

Momčilović, Z., \& Momčilović, V. (2016). Attitudes of the students of the Teacher-Training Faculty in Vranje towards physical education. Facta Universitatis Series Physical Education and Sport, 14(3), 455-462.

Rakovac \& Heimar, (2003). Utjecaj kondicijske pripreme tipa jakosti i snage na živčani imišićni sustav sportaša (Influence of fitness preparation of the strength type on the nervous and muscular system of athletes). In D. Milanović \& I. Jukić (Eds.). Conditional preparation of athletes, (pp. 180-184). Zagreb. In Croatian

Višnjić, D. (2006). Nastava fizičkog vaspitanja od 5-og do 8-og razreda osnovne škole: priručnik za studente, nastavnike i profesore (Physical Education classes from 5th to 8th primary school grades: Handbook for students, teachers and professors). Belgrade: Zavod za udžbenike i nastavna sredstva. In Serbian

Šoše, H., \& Rađo, I. (1998). Merenje u kineziologiji (Measurement in kinesiology). Sarajevo: Faculty for Physical Culture.

Zatsiorsky, V.M., \& Kraemer, W.J. (2006). Science and practice of strength training, Second Edition. Champaign, IL: Human Kinetics. 


\section{EFEKTI EKSPERIMENTALNOG MODELA EKSPLOZIVNE SNAGE U REDOVNOJ NASTAVI FIZIČKOG VASPITANJA}

Istraživanje je izvršeno sa ciljem da se utvrde efekti treninga eksplozivne snage na transformaciju motoričkih i funkcionalnih sposobnosti u redovnoj nastavi fizičkog vaspitanja kod učenika osnovnih škola. Uzorak ispitanika činilo je 64 učenika u Nišu, Srbija, uzrasta 14 godina. Eksperimentalna grupa bila je sastavljena od 32 ispitanika, odabranih za trening eksperimentalnog modela eksplozivne snage u glavnom delu časa redovne nastave fizičkog vaspitanja, tri puta nedeljno po $45 \mathrm{~min}, u$ trajanju od osam nedelja. Jedna polovina od tih časova realizovana je progamom redovne nastave fizičkog vaspitanja, a druga polovina eksperimentalnim modelom eksplozivne snage, u trajanju od četri nedelje. Kontrolna grupa je bila sastavljena takođe od 32 ispitanika, koji su pohađali časove redovne nastave fizičkog vaspitanja, tri puta nedeljno po $45 \mathrm{~min}$, u trajanju od osam nedelje. Za procenu motoričkih sposobnosti kod obe grupe ispitanika primenjeno je osam motoričkih testova: za procenu koordinacije (dva), sprinterske brzine (dva), repetitivne snage (dva) i eksplozivne snage (dva). Za procenu funkcionalnih sposobnosti primenjeni su tri testa: frekvencija pulsa posle opterećenja, Margarija test $i$ vitalni kapacitet pluća. Za obradu podataka primenjena je analiza varijanse $i$ kovarijanse. Rezultati istraživanja su pokazali da je eksperimentalna grupa ispitanika postigla bolje rezultate u motoričkim i funkcionalnim sposobnostima, kao i da je došlo do statistički značajnih efekata na finalnom testiranju.

Ključne reči: trening eksplozivne snage, motoričke sposobnosti, funkcionalne sposobnosti, učenici osnovnih škola, efekti. 